\title{
Changing a Hindu temple into the Indrapuri Mosque in Aceh: the beginning of Islamisation in Indonesia - a vernacular architectural context
}

\author{
Alfan $^{1}$, D. Beynon ${ }^{1} \&$ F. Marcello ${ }^{2}$ \\ ${ }^{1}$ Faculty of Science, Engineering and Built Environment, \\ Deakin University, Australia \\ ${ }^{2}$ Faculty of Health Arts and Design, Swinburne University, Australia
}

\begin{abstract}
This paper elucidates on the process of Islamisation in relation to vernacular architecture in Indonesia, from its beginning in Indonesia's westernmost province of Aceh, analysing this process of Islamisation from two different perspectives. First, it reviews the human as the receiver of Islamic thought. Second, it discusses the importance of the building (mosque or Mushalla) as a human praying place that is influential in conducting Islamic thought and identity both politically and culturally.

This paper provides evidence for the role of architecture in the process of Islamisation, by beginning with the functional shift of a Hindu temple located in Aceh and its conversion into the Indrapuri Mosque. The paper argues that the shape of the Indrapuri Mosque was critical to the process of Islamisation, being the compositional basis of several mosques in other areas of Indonesia as Islam developed. As a result, starting from Aceh but spreading throughout Indonesia, particularly to its Eastern parts, Indonesia's vernacular architecture was developed by combining local identity with Islamic concepts.

Keywords: mosque, vernacular architecture, human, Islamic identity, Islamisation.
\end{abstract}




\section{Introduction}

Indonesia is an archipelago country, comprising big and small islands. It is located between Asian and continents with 1,919,440 $\mathrm{km}^{2}$ of land and $3,273,810 \mathrm{~km}^{2}$ of the sea (see fig 1) [1]. Indonesia has very strategic position to reach from many countries around the globe. Aside from an easiness to reach, Indonesia owns fertile lands, which mostly produce spices and camphor. Before Christ (BC) in the west of Sumatera Island, there was a city called Barus. It was an international port, which used to be a port of call for commercial ships from various countries such as those in the Middle East, India, Europe, China, etc. Since then, Indonesia was known by many countries in the world, and thus, such inter state's relationships simplified the arrival of a new religion for Indonesia.

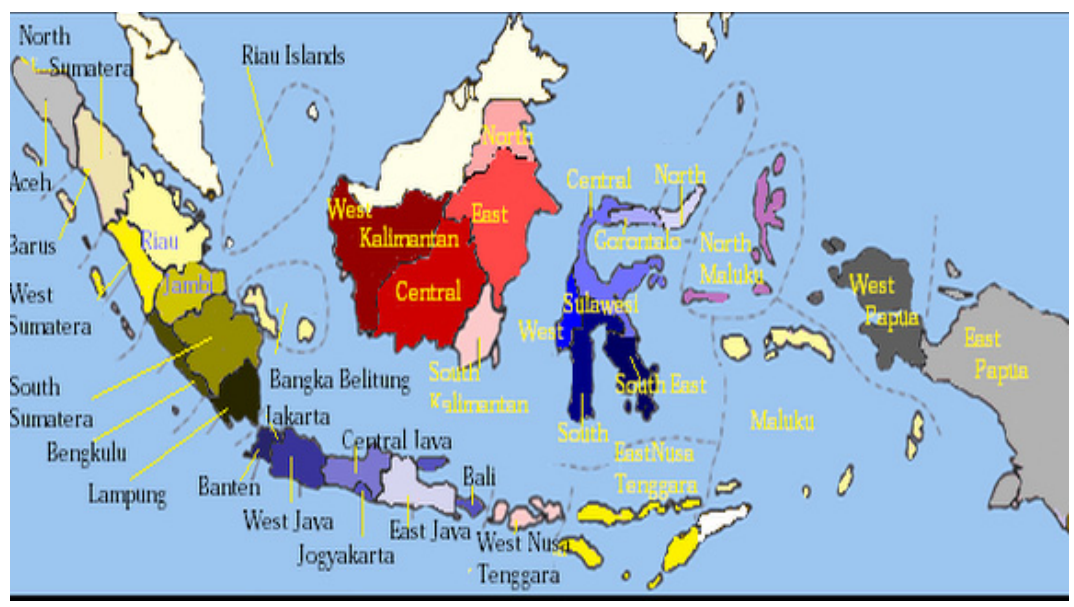

Figure 1: $\quad$ Map of Indonesia.

There seems to be a similar pattern in terms of arrival of a new region into Indonesia. The pattern employed was an interaction between regional merchants and abroad merchants who brought up to date doctrine or new-born religion. Overseas merchants such as from the Middle East, India and China came to Indonesia, in addition to performing trading, also spread religious belief in local merchants and close at hand people. This pattern had been implemented when Hinduism and Buddhist were brought by Indian and Chinese's merchants to Indonesia. Subsequently, as centuries passed, Moslem merchants from the Middle East, India as well as China also employed the same pattern, spreading Islamic doctrine to Indonesian merchants and the people living near the port. Eventually, a community was slowly established that believed in the new religion.

Before the arrival of Islam in Indonesia, Hinduism and Buddhism had been developed in Indonesia. The development of Hinduism and Buddhism can be proved by many royal kingdoms based on beliefs of Hinduism and Buddhism. In addition, there are also architectural relics such as temples, statues and so forth. 
In such condition, Islam penetrated and its doctrine grew in Indonesia, albeit requiring a relatively long period. In other words, Islamisation in Indonesia from the side of belief, social order, and in an architectural context took centuries to come to a realisation.

This paper discusses two things, the first to argue when to enter and develop the teachings of Hinduism and Islam in Indonesia. The second, discusses the Islamisation process in an architectural context.

\section{History of Hinduism}

Ardhana argues that Hinduism is also referred to as Sanata Dharma, which means eternity. The term Hindu constitutes a part of expression change from the term Sindhu. Hinduism doctrine was brought by Arya's people from Central Asia to India and setting nearby Sindhu River. In the hill of the river, Hinduism religion grew.

The Arya people came to Indonesia in a wave, particularly to the Punjab region until this region was funded by the heirs of Arya, thus maintaining its ancestries, prevented from being merged with native ethnic of India. In addition to Punjab, the Arya people also came to other regions in India such as Doab. Here, the people of Arya lived in intercourse with the native ethnic of India, Dravida. It resulted from the intercourse of both ethnics was Hindu culture.

The Hinduism holy book is Vedas. The Vedas contains religious knowledge about the universal soul, Brahman, Sang Hyang Widhi (The Lord God). There are several positions concerning the revelation of the Vedas. The first position proposed by the Eastern civilisation experts suggests that the Vedas was revealed in $1500 \mathrm{BC}$. The second argues it was revealed in $3000 \mathrm{BC}$. While others argue it was in $6000 \mathrm{BC}$.

Hinduism has three fundamental beliefs: Tattwa (essence), decency (ethic) and ritual. These three foundational beliefs do not stand alone, but complement one another, thus making the execution of Hinduism doctrine perfect. These basic frameworks of Hinduism are like an egg, where in the tattwa is egg yolk, the ethic is egg white, and the ritual is eggshell. When one of them is absent, the egg is imperfect. Accordingly, Hinduism greatly emphasizes the balance between the essence, ethical and ritual [2].

\subsection{Arrival and growth of Hinduism in Indonesia}

Ardhana says that Hinduism in Indonesia came from India. It was spread from India to Indonesia by Brahmanas or bachelor of Hinduism. Hinduism arrived in Indonesia from bringing the concept of a caste system. The caste system which grew in India included Bramins who were religious people (priestly people), Kshatriyas who were noblemen or kings, Vaishyas who were merchants, and Shudras who were the majority of people or laboring class. Meanwhile, Indonesia's people prior to the arrival of Hinduism in Indonesia did not recognize the caste system in the society. Thus, the arrival of Hinduism in Indonesia was performed by force. At last, the battle took place between Hindus group and 
common people who did not expect any caste system in the community. The battle was won by the Hindus group while the losers escaped to a hinterland. Then, the Hindus group continued to develop their doctrine in Indonesia [2].

In Indonesia, caste vaisya as a place for groups of traders in the social order of Hindu religion, Hindu caste system was eliminated from Indonesia. This is because the caste vaisya is the lowest caste in Hindu society. By eliminating the caste Hindu significant role in Indonesia to be dissimilar with a Hindu in India, because there is no caste of merchant groups that bolster their economies. This case is different from the caste Vaishya in India, which could increase international trade.

Lombard argues that caste system in the Hindu religion is not only found in the Hindu social structure but also found in the use of the Java language, Sundanese, and Madurese. For example, The Ngoko language is an informal language of the Java language and the Kromo Inggil is a formal language in the Java language. Similar to Java's language, Sundanese and Madurese have a level of language [3].

\subsection{The Hindu kingdoms in Indonesia}

Based on the Indonesian history, the Hindu kingdom actually grew not only in Aceh, but also Eastern Indonesia, such as from Sumatera Island, to Java, Bali and Kalimantan. The growth of Hinduism was followed by the growth of Hinduismbased kingdoms. From the cultural, social and political perspective, Hinduism had acquired a place before the people of Indonesia, indicating how strong the power of Hinduism in Indonesia was.

\subsubsection{Hindu kingdoms in West Sumatera}

According to liata, in the year $500 \mathrm{BC}$ existing Poli Hindu kingdom in Aceh Besar. The kingdom has 136 villages. Evidence of the effect of poly Hindu kingdom in Aceh, on the naming of a place that uses such as term or Hindi: Indrapuri village, Indraputra, Gandapura, King, king of Commerce, etc. besides poly Hindu kingdom, Liata also said their other Hindu kingdom, the kingdom of Hindu Indrapura, Tai Shi or Tajik [4]. The next Hacky added their Lamuri Hindu kingdom located in Aceh big [5].

In addition in Sumatera Island, there are also some Hindu kingdoms such as the Pagaruyung kingdom in Batusangkar - West Sumatera. In South Sumatera, there was the Sriwijaya kingdom and in Lampung, there was the Tulang Bawang kingdom.

\subsubsection{Hindu kingdoms in Java and Bali}

On the Island of Java and Bali, there were some Hindu kingdoms, such as in Java were Tarumanegara Hindu kingdom, the Kediri Hindu kingdom, and the Majapahit Hindu kingdom. In Bali, there was Buleleng Hindu kingdom. Based on inscriptions found, Tarumanegara kingdom is located between Citarum and Cisadane Rivers. The kingdom grew in the 5th century, and the king was Purnawarman. Other Hindu kingdoms in Java Island are Ancient Mataram situated in Central Java, which grew in the 8th century, the Kediri kingdoms which is 
located in Kediri, and Majapahit with the popular governor known as Pati Gajah Mada. Gajah Mada, which is famous for its Palapa oath, with the strong intention to unite all the kingdoms in the archipelago. Furthermore, Ajim said that in the area of Bali in the 17th century $\mathrm{AD}$, there was a kingdom of the Buleleng kingdom, located in the northern part of the island of Bali [6]. This kingdom was a Hindu kingdom, later transformed into the Islamic empire. In this, areas are now many Muslim communities living at this place.

\subsubsection{Hindu kingdoms in Kalimantan Island}

In Borneo Island, there was Kutai kingdom. The location of the Kutai kingdom was in an area Muarakaman by the River Mahakam in East Kalimantan. His first king was Kudungga, later replaced by Aswawarman. One of the relics was the Kutai kingdom. Kutai is the inscription carved on a stone pillar called Yupa, found on the Mahakam river basin in East Kalimantan.

Kutai Kingdom was established in the 4th century BC in the Mahakam River in East Kalimantan. The first King of Kutai kingdom was Kudungga. Then Kudunga was replaced by Aswawarman. One of the relics of the Kutai kingdom is the inscription carved on a stone pillar. The stone pillar also called Yupa. It was found on the Mahakam river basin in East Kalimantan.

\subsection{Hindu architecture}

According to Putra, the architecture served as a symbol of social culture [7]. Hinduism architecture is now mostly found in Bali. The majority of Balinese people are Hindus, different from other regions in Indonesia, where in Hinduism is the religion of the minority. The Hindu architecture in Bali constitutes an illusion when all regions in Indonesia were controlled by Hinduism, and we can certainly imagine how a considerable number of architectures with Hinduism identification. For now, Balinese architecture may be used as a reference for Hindu architecture (figure 2).

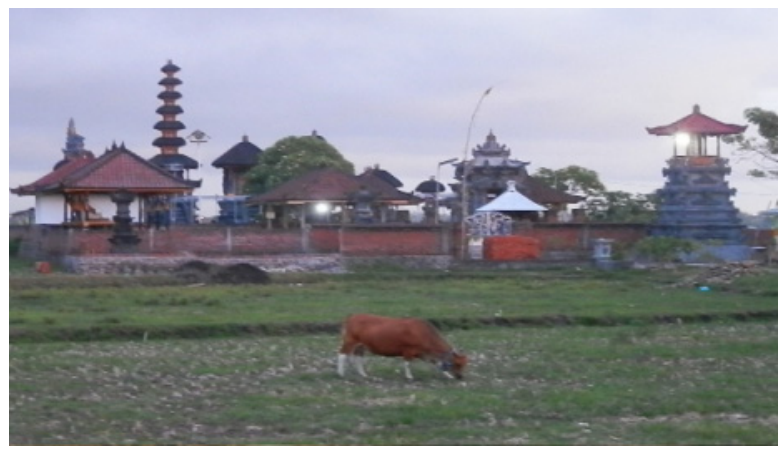

Figure 2: $\quad$ Hindu architecture in Bali.

According to Gomudha, the basic framework of architecture is based on three beliefs: Tattwa (philosophy), ethical and ritual. Tattwa (philosophy) is like "head", 
which encompasses the philosophy of God, cosmos, life, and livelihood. Ethics are like "heart" which encompasses knowledge about the good and noble attitude in line with definitions of dharma (truth) and yadnya (holy sacrifice) for Hindus. While, the ritual is like "foot" which is a holy sacrifice, which is obligatory for every Hindu [8].

\subsubsection{Types of Hindu architecture}

Meganada says that in general, there are two forms of Hindu religious architecture, namely:

1. Temple;

2. Castle.

A temple is a center of religious activities, where the people perform transcendent connection with the God while a castle is a place where the king and his family are buried [9].

\subsubsection{Types of temples in Bali}

According to Meganada that there are three types of temple in Bali.

1. Meru Temple;

2. Padmasana Temple;

3. Gedong Temple.

Meru Temple is a building having laid out with a square shape, made of a wooden frame structure with the terraced roof from stages 1, 3, 5, 7, 9, and 11 (see figure 3). The function of Meru Temple is in accordance with Mpu Kuturan concept. In addition, to serving as a place to praise and worship Ida Sang Hyang Widhi was. Along with its manifestation, Meru Temple is also functioned as the place to praise and worship Atma Sidhadewata.

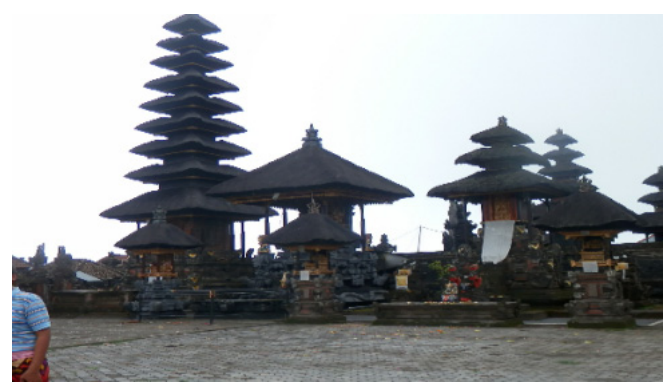

Figure 3: $\quad$ Meru in Bali.

Padmasana Temple is a lotus throne as the place to praise the manifestation of Ida Sang Hyang Widhi Wasa. The building structure is massive with square foundation using beautiful and animal ornaments such as: turtle (bedawang nala), dragon (anantha boga dragon, basuki dragon, and taksaka dragon), elephant (Karang Gajah), scorpion (Karang tapel), bird (karang goak, garuda, goose), plantation, etc.

Gedong Temple or pelinggih gedong, the site of building foundation is square or elongated rectangular. The shape of the building is massive walled made of red 
brick, also serving as building load supporting wall, wooden roof with material made of ijuk (palm fiber). Alternatively, pillars are employed as a roof supporter. Another characteristic is that it is equipped with a door on the building wall. Meanwhile, the function of Gedong Temple or Pelinggih Gedong is used as the place to keep magical or sacred objects. The shape and size of room are varied in accordance with the quantity of rooms needed [9].

\section{Islamisation in Indonesia}

Islamisation in Indonesia may be viewed a couple of different perspectives: Islamic doctrine and architectures. Both were supporting each other in the Islamisation process in Indonesia. From the perspective of Islamic doctrine, many arguments are proposed in determining when Islam arrived in Indonesia, where Islam first arrived, and where it was from. To disclose it, written evidence are required. It is very difficult to acquire written data because it occurred more than 14 centuries ago. On the other hand, when and where the Islamisation process first occurred and where the Islamic growth was further oriented in Indonesia may be traced based on the architectural context. Furthermore, both Islamisation contexts are described below.

\subsection{Arrival of Islamic doctrine in Indonesia}

According to Simanullang, Islamic doctrine in Indonesia first arrived from coastal regions and grew to highlands. In accordance with the history, Islam first arrived through a coastal region of Barus City in the 7th century [10], and grew to the coastal region of Aceh, wherein in this place. Zein explains that Islam established the first Islamic kingdom called Lamuri Islamic kingdoms in 1205. Then, in 1267, there was established Samudra Pasai Islamic kingdom in Aceh.

The arrival of Islam in Barus City was first brought by Arabic merchants who had previously built a trade relation with Indonesia. The trade relation grew in line with Islamic doctrine broadcasting relation by the Arabic merchants who had first made Islam their religion. The historical evidence which can be used as a reference that the Islamic doctrine grew in the 7th century is a heritage of tombstone in Barus City, and the finding of the Islamic Arabian village has proved that the Islamic doctrine had penetrated into Barus City by the Arabian, rather than Indian. The Islamic kingdom was established after waiting for more than six centuries since its arrival in the 7th century. It may be understood because for hundreds of years ago before the 7th AD, Aceh had the Hindu kingdom, which was very strong in undergoing Hindu doctrine, plus strong culture, social and politics of the Hindu kingdom at that time. This also indicates that the arrival of Islam was performed peacefully, and without any force imposed on the local people. Fortunately, in Islamic doctrine, Islam does not recognize the caste system in the society. Then, trade contact took place between Arabian Moslem merchants and a group of Vaishya caste, wherein the society in this group had a profession as merchants. Vaishya caste is the lowest caste in the social structure of Hinduism. This trade relation made the group of Vaishya in Hinduism would easily be 
oscillated, and they felt more respected by their new religion, Islam, because, in Islam, what makes different between one and another is only their faith in God. So, the most important are their adherence in their Creator, Allah SWT.

In addition to the Islamisation process through trading, Sulasman added, there are several methods in Islamisation in Indonesia, marriage, education, arts, and political process [11]. These Islamisation methods accelerated the Islamic growth in Indonesia, increased the number of Islamic followers and developed Islamic kingdoms in Indonesia. Thus, politically, the presence of Islam in Indonesia was particularly strong.

\subsection{Islamisation in a building context}

Islamisation in building context is that Islam adopts the certain religion's building or building style to be a supporter of Islamisation activities, for example, temple building, churches, etc. Before the function was changed in accordance with the Islamisation activities, Islam should first make sure that all ornaments in the building were not needed by the Islamic doctrine.

\subsubsection{Indrapuri Mosque style in Aceh as the main idea of Islamisation in an architectural context}

Indrapuri Mosque is one of the heritages of Hinduism in the form of temple in Aceh Besar (see figure 4). As reported by Zein, Indrapuri Mosque is the evidence of the occurrence of cultural evolution and ideological revolution [12].

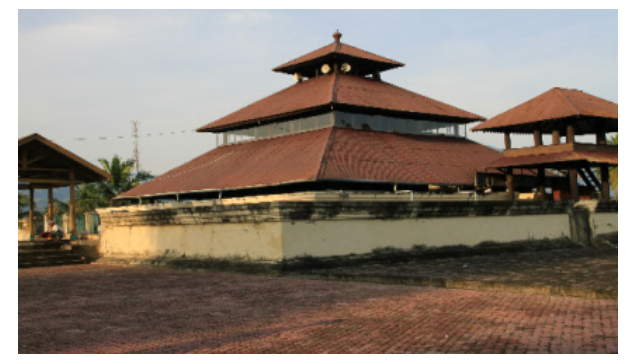

Figure 4: Indrapuri Mosque in Aceh.

Kompas argues that Indrapuri Mosque in Aceh was built in the 10th century $\mathrm{AD}$ by the Lamuri kingdom. At the time, it functioned as the Temple of Hinduism [4]. In addition, Zein says that the function of the temple was changed into a Mosque when the King and the people of Lamuri Hindu kingdom converted to Islam in $1205 \mathrm{AD}$. This conversion took place after the Lamuri kingdom received assistance from Syech Abdulah Kan'an known as Tengku Abdulah Lempeuneuen from Peureulak, East Aceh and Johan, a prince, the Crown Prince of Lingga kingdom. They helped the Lamuri kingdom after having been attacked by a group of pirates from China. The battle was finally won by the Lamuri kingdom after both Moslem acquired karomah (Walli Allah). As a present for both of them, the King and the people were willing to convert to Islam. After converting to Islam, 
many Hindu temples were unused. Therefore, the people had the initiative to turn Indrapuri Temple into a Mosque. Because the building was still fit to use and different from Indrapatra and Indrapurwa Temples, which had been damaged and could no longer be used. Such intention was informed to the King, and he approved the functional transfer of the building. Then, the people worked together to clean the temples away from any statues and sculptures from the temples [12].

The conversion of Indrapuri Temple into Indrapuri Mosque in 1205 AD may be deemed to have an initial process of architectural. The change in function of the temple into Mosque whose shape of the roof similar to the pyramid with three layers is used as a style of mosque building for the establishment of new mosques in other regions in the archipelago. Alfan, Beynon, and Marcello argue that the usage of this shape is one of the Islamic strategies in spreading the Islamic doctrine in the archipelago [13].

\subsubsection{Islamisation in West Sumatera in an architectural context}

Many mosques are based on the shape of mosques Indrapuri Aceh, in West Sumatra. They are proving physically buildings that have occurred in West Sumatra Islamisation process in the context of an architecture (see figs 5, 6 and 7).

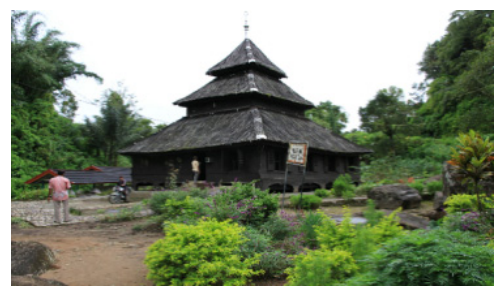

Figure 5: Kayu Jao Mosque in Solok, West Sumatera.

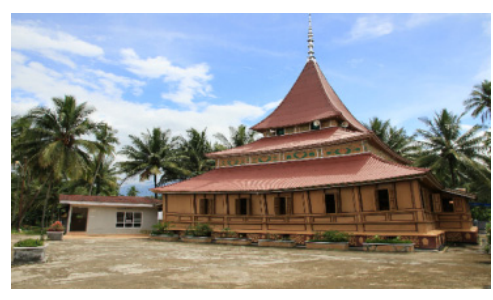

Figure 6: Koto Nan Ampek Mosque in Payakumbug, West Sumatera.

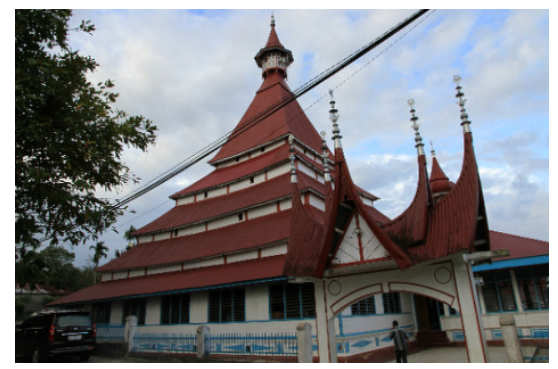

Figure 7: $\quad$ Limo Kaum Mosque in Batusangkar, West Sumatera.

\subsubsection{Islamisation in Riau in an architectural context}

As with other areas in Indonesia region, in the province of Riau also contained a mosque building which forms the roof is also based on the shape of the roof of the 
mosque Indrapuri Aceh. The mosque is a Jami' Air Tiris Mosque, which is similar to the shape of the roof of the mosque Indrapuri in Aceh. A form of the building roof is a pyramid-shaped that is composed of three layers. The Jami Air Tiris mosque was built in $1901 \mathrm{AD}$ (see fig. 8).

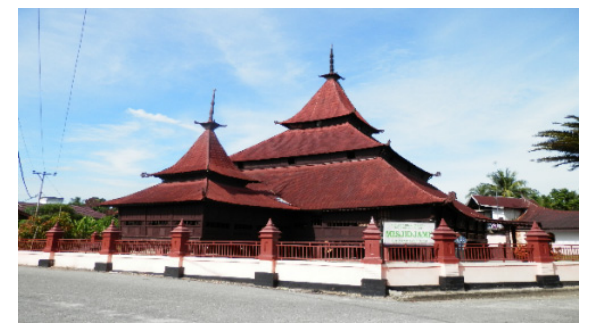

Figure 8: Jami’ Air Tiris Mosque in Riau.

\subsubsection{Islamisation in Java Island in an architectural context}

In Java also occur Islamisation of Architecture, namely the presence of a mosque shape based on the shape of Indrapuri mosque in Aceh. For example, Demak Mosque located in Central Java and Banten Mosque in Banten (see figs 9 and 10).
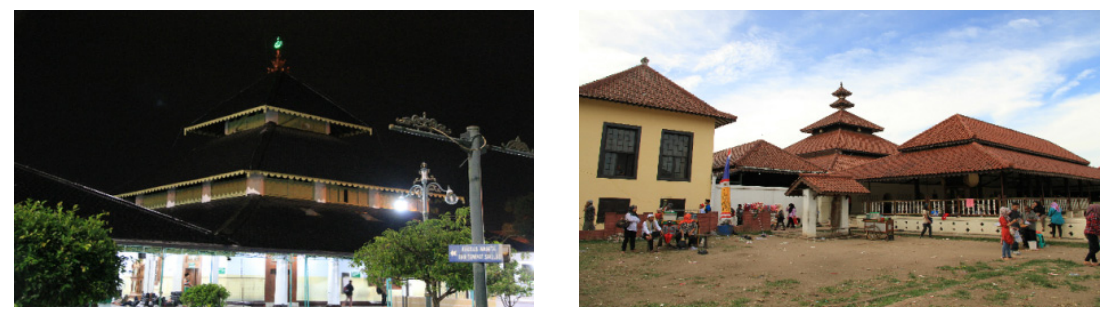

Figure 9: Demak Mosque in Demak, Figure 10: Banten Mosque in Banten. Central Java.

\subsubsection{Islamisation in Bali Island}

Similar to other regions in Indonesia, architectural Islamisation process also occurred in Bali, for example, Loloan Mosque. Until present, Hinduism still becomes the religion of the majority of people of Bali (see fig. 11).

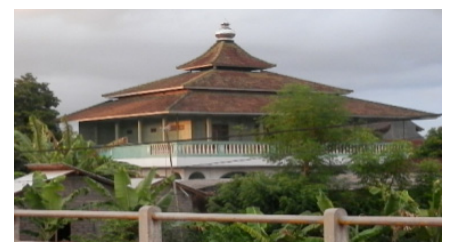

Figure 11: $\quad$ Loban Mosque in Bali. 


\section{Conclusion}

Based on the historical evidence, Hindu kingdom existed since $500 \mathrm{BC}$ in AcehSumatera Island, and therefore, it evidently indicates that the arrival and the growth of Hinduism in Indonesia began from Aceh and grew to other regions through western Indonesia. Furthermore, the Hindu kingdom of Poli in Aceh proves that this Hindu kingdom was the first and oldest the Hindu kingdom in Indonesia, rather than to the regions of Kutai kingdom in Kalimantan Island. Logically, Aceh is closer to India than to the regions of Kutai kingdom to India. Because Hinduism came from India and human movement at that time through the sea by using the ship.

The Changes in the function of the Indrapuri temple into an Indrapuri mosque have gone in the 13th century in Aceh. This changes as the beginning of a process of Islamisation in the architectural context. The people of the Barus communities have embraced Islam since the 7th century. However, it is difficult to find evidence in forms of Islamic architecture, built in the seventh century, which is still functioning until now.

The use of the Indrapuri mosque building model is to facilitate the process of Islamisation of Indonesian west to the eastern part of Indonesia. The use of this form of a mosque would not conflict with the Hindu community. The shape of the building of this mosque is very familiar with Hindu society because this building, there are similarities with Hindu religious buildings.

\section{References}

[1] http://www.invonesia.com/luas-wilayah-negara-indonesia.html 9:38 am $8 / 1 / 2016$

[2] Ardhana, Suparta, Sejarah Perkembangan Agama Hindu, Paramita, Surabaya, 2002.

[3] Lombard, D, Nusa Jawa: Silang Budaya, Jilid 2, Jaringan Asia, Gramedia, Jakarta, 2000.

[4] Kompas, http://travel.kompas.com/read/2009/08/27/08461068/menengok. masjid-masjid.bersejarah.di.aceh 10:28 am 21/1/2016

[5] Liata, Nofa, https://nofalliata.wordpress.com/agama-islam-dan-sektesektenya/dari-hinduisme-hingga-islamisasi-di-aceh/ 12:17 pm 11/1/2016

[6] Ajim, Nanang, http://www.mikirbae.com/2015/10/kerajaan-buleleng-dankerajaan-dinasti.html 11:34 am 26/1/2016

[7] Putra, I Gusti Made, Puri Cikal Bakal Kota Modern di Bali, in Suica, Ngakan Putu, Pustaka Arsitektur Bali, Ikatan Arsitek Indonesia Daerah Bali, pp. 65-75, 2008.

[8] Gomudha, Wayan, Jelajah Arsitektur Hunian Tradisional Bali, in Sueca, Ngakan Putu, Pustaka Arsitektur Bali, Ikatan Arsitek Indonesia Daerah Bali, pp 85-98, 2008.

[9] Meganada, Wayan, Arsitektur Pura di Bali, in Sueca, Ngakan Putu, Pustaka Arsitektur Bali, Ikatan Arsitek Indonesia Daerah Bali, pp. 6-63, 2008. 
96 Islamic Heritage Architecture and Art

[10] Simanullang, Zuardi Mustafa, Barus Kota Wisata, Religi Sejarah dan Budaya, Kelompok Sadar Wisata Mahligai, Barus.

[11] Sulasman \& Suparman, Sejarah Islam di Asia \& Eropah, Pustaka Setia, Bandung, p. 286, 2013.

[12] Zein, Abdul Baqir, Masjid-masjid bersejarah di Indonesia, Gema Insani, pp. 22-24, 1999.

[13] Alfan, Alfan, Beynon, David and Marcello, Flavia, The design of architectural dialect and local identity as Islam strategy in promoting its thought in Indonesia. Proc. in HISTART 2013: Politics, Identity, Ideology: History of Art Conference, Mimar Sinan Fine Arts University, Findikh, Istanbul, pp. 111-120, 2013.

[14] Hacky, Fardelyn, http://www.kompasiana.com/fardelynhacky/lamuri-situssejarah-yang-nyaris-mati_5528223c6ea834d9418b45af 2:36 pm 11/1/2016 